\title{
ІНФОРМАЦІЯ ПРИВАТНОГО ХАРАКТЕРУ 3 ОЗНАКАМИ ТАЄМНИЦІ В КРИМІНАЛЬНОМУ ЗАКОНОДАВСТВІ УКРАЇНИ ТА ГРУЗІЇ КРІЗЬ ПРИЗМУ ЗАРУБІЖНОГО ДОСВІДУ
}

Хлопов А. $О$.

у статmі досліджуються питання кримінально-правової охорони інформації приватного характеру з ознаками таємниці за законодавством України та Грузії. Розглядається низка спільних та відмінних рис кримінального законодавства зазначених країн, аналізуються закладені переваги та недоліки кожного з них. У розрізі дослідження в приклад наводиться досвід інших країн Європи, особливо че стосується сфери вдосконалення кримінальної відповідальності та інших актуальних питань.

Окремо розглядаються питання регламентації відповідальності фізичних та юридичних осіб. Пропонується на законодавчому рівні остаточно відповісти на питання доцільності регламентувати відповідальність юридичних осіб у межах кримінального законодавства, тим самим усунути наявну в правовому колі невизначеність. Висунуті пропозиції щодо врахування окремих положень зарубіжного досвіду задля підвищення ефективності вітчизняного правового регулювання загалом та особливо відповідального за охорону інформації приватного характеру з ознаками таємниці. Паралельно акцентується на проблемних моментах Кримінального кодексу України, який повільно адаптується до сучасного рівня розвитку суспільних відносин, особливо у сфері охорони інформації приватної життєдіяльності людини та кримінологічної ситуації в країні.

Значний блок відводиться розгляду проведених реформ правоохоронної системи в Грузії. Розглядається їх результативність (зменшення злочинності, підвищення довіри до державних інституцій), аналізується негативний бік вказаних реформ, що також мав місце. Наголошується на недоцільності сліпого перенесення зарубіжного досвіду на українські реаліі. Разом із тим пропонується враховувати прогресивні законодавчі підходи зарубіжних країн шляхом їх перейняття з урахуванням вітчизняних умов.

Порівнюється кількість скоєних злочинів у розрізі досліджуваних країн та оцінюється рівень латентності злочинів в Україні. У підсумках звертається увага на напрями вдосконалення вітчизняного законодавства і необхідністьі проведення державної політики у відповідній сфері.

(с) Хлопов А. О., 2020
Ключові слова: Україна та Грузія, кримінальний кодекс, кримінальна відповідальність, зарубіжний досвід, інформація приватного характеру з ознаками таємниці, таємниця.

Khlopov A. O. Information of private character with signs of secrecy in the criminal legislation of Ukraine and Georgia through the prism of foreign experience

The article examines the issues of criminal-legal protection information of private character with signs of secrecy under the legislation of Ukraine and Georgia. A number of common and distinctive features between the criminal legislation of these countries are considered, the inherent advantages and disadvantages of each of them are analyzed. In the context of the study, the experience of other countries is cited as an example, especially in the area of improving criminal responsibility and other topical issues.

Issues of regulation of liability of individuals and legal entities are considered separately. It is proposed to finally answer at the legislative level the question of the expediency of regulating the liability of legal entities within the framework of criminal legislation, thereby eliminating the uncertainty existing in the legal field. Proposals have been put forward to take into account certain provisions of foreign experience in order to increase the effectiveness of domestic legal regulation in general, and especially those responsible for protecting the information of private character with signs of secrecy. At the same time, attention is focused on the problematic aspects of the Criminal Code of Ukraine, which is slowly adapting to the current level of development of public relations, especially in the field of information protection of private life and the criminological situation in the country.

A significant block is devoted to the consideration of the reforms of the law enforcement system in Georgia. Their effectiveness is considered, namely, the reduction of crime, increased confidence in state institutions, and the negative side of these reforms, which also took place, is analyzed. It is noted that it is inexpedient to blindly transfer foreign experience to Ukrainian realities. At the same time, it is proposed to take into account the progressive legislative 
approaches of foreign countries by adopting them, taking into account domestic conditions.

The article compares the number of crimes committed in the context of the countries under study and estimates the level of crime latency in Ukraine. The results draw attention to the directions of improving domestic legislation and the need for state policy in the relevant area.

Key words: Ukraine and Georgia, criminal code, criminal liability, foreign experience, information of private character with signs of secrecy, secrecy.

Постановка проблеми та іï актуальність. Ефективне правового регулювання істотно залежить від змоги законодавчих норм виконувати покладених на них завдань. Нині варто визнати, що чинний Кримінальний кодекс України (далі - КК України), що діє вже друге десятиліття, потребує осучаснення. 3 одного боку, потребує розвантаження, крок до якого зроблено шляхом введення інституту кримінальних проступків, з іншого потрібен перегляд чинних норм, які застарілі і не забезпечують достатнього рівня охорони різних сфері недоторканності приватного життя. Неабияку користь у цьому становить вивчення та узагальнення зарубіжного досвіду, адже це спрощує пошук оптимального варіанту регулювання тих чи інших сфер для вітчизняного законодавства. Особливо актуальним це є виглядає для кримінально-правової охорони різних видів інформації приватного характеру, де, незважаючи на правові системи, відбувається поступова уніфікація законодавчих підходів до розуміння тих чи інших понять. Такий тренд $\epsilon$ логічним, адже всі демократичні країни забезпечують дотримання основних прав і свобод людини, а такі інституції, як Європейський суд із прав людини, сприяють цьому. 3 цього приводу розумно приєднатися до Ю.В. Бауліна, який зазначає, що останнім часом виникла тенденція до зближення різних кримінально-правових систем між собою, їх взаємопроникнення та взаємозв'язку [1, с. 33]. Яскравим прикладом $\epsilon$ Європейський Союз: він $\epsilon$ наддержавним утворенням, його приписи успішно співіснують із нормами країн спільноти, не відміняючи, а доповнюючи їх, що цілком відповідає сучасним глобалізаційним процесам.

Аналіз останніх досліджень і публікацій. Питаннями дослідження зарубіжного досвіду у сфері кримінально-правового регулювання займалася чимало науковців, серед яких П.С. Берзін, В.І. Борисов, С.Я. Бурда, Є.В. Валькова, О.О. Михайлов, Л.А. Наконечна, Р.П. Олійничук, М.С. Пизирьов, Г.В. Федотова, М.І. Хавронюк,
О.Ю. Шличек, А.М. Ященко та інші. Однак сфері охорони інформації приватного характеру з ознаками таємниці з боку кримінально-правових норм дослідники не приділяли гідної уваги, розглядаючи лише окремі аспекти без комплексного вивчення. Маловивченим виглядає і досвід законодавчих та структурних реформ Грузії, де, попри суттєві недоліки, вдалося значно покращити криміногенну ситуацію в країні. Так, згідно з даними глобальної бази Numbeo за 2019 р., Грузія за індексом протидії злочинності посідає 6 місце в світі, а Тбілісі стабільно входить до 20 найбільш безпечних міст світу. Україна за цим індексом посідає 79 місце ${ }^{1}$, а Київ перебуває навіть не в першій сотні серед великих міст світу. Крім того, в останні роки Україна показує тенденцію до зниження показників, на відміну від Грузії, яка з 2012 р. стабільно визнається однією з найбільш безпечних країн світу.

Метою статті $\epsilon$ аналіз законодавства України та Грузії у сфері кримінально-правової охорони інформації приватного характеру з ознаками таємниці шляхом дослідження спільних та відмінних рис, виявлення прогресивних підходів та недоліків i запропонування напрямів вдосконалення вітчизняного закону з огляду на викладене.

Виклад основного матеріалу. Почати варто з розгляду особливостей формування кримінального законодавства в України та Грузії. Чинний Кримінальний кодекс Грузї (далі - КК Грузії) був прийнятий майже на два роки раніше українського візаві - 22 червня 1999 р., тим самим змінивши Кримінальний кодекс Грузинської РСР 1960 р. При його укладенні за основу були взяті положення Модельного кримінального кодексу для країни Співдружності Незалежних Держав, перенесеного з урахуванням стану справ на той момент у країні. 3 цього приводу В.В. Лунєєв зазначає, що цим кодексом був продовжений тренд на збільшення кількості криміналізованих діянь шляхом розширення меж кримінально-правового регулювання [2, с. 260]. Така практика $\epsilon$ передбачуваною, адже на момент ухвалення нового кодексу його попередник зазнав значної кількості змін та доповнень, але, попри це, не міг покрити всього спектра суспільних відносин. Схожою $є$ ситуація й в Україні, де прийнятим 5 квітня 2001 р. КК було криміналізовано 79 нових складів злочину при лише 40 декриміналізованих [3, с. 613, 621]. Тим самим оновлене кримінальне законодавство України та Грузії позбавилося цілої низки застарілих норм

\footnotetext{
1 Numbeo - це глобальна база даних про споживчі ціни, передбачуваний рівень злочинності, медичного обслуговування та інша статистика.
} 
радянських часів, паралельно поширюючи сферу кримінально-правового регулювання на нові суспільні відносини, що проходили повз увагу попередніх кодексів.

Інформація приватного характеру, будучи категорією, що об'єднує значне коло відомостей про різні аспекти приватної життєдіяльності людини, займає особливе місце в сучасному світі. Далеко не завжди законодавство вчасно реагує на суспільні запити, виконуючи роль наздоганяючого, що особливо притаманне правовому регулюванню пострадянських країн. Звертаючись до норм, що регламентують охорону інформації приватного характеру з ознаками таємниці, в межах КК Грузії варто зазначити, що більшість із них послідовно розміщені у Главі XXIII кодексу «Злочини проти прав і свобод людини». Зокрема: ст. 157 «Посягання на особисту або сімейну таємницю, інформацію, що відображає особисте життя, або персональні дані» - щодо зберігання та обігу інформації про різні аспекти приватного життя; ст. 158 «Порушення таємниці приватної комунікації» - стосовно самовільного запису та прослуховування приватних переговорів чи іншого протиправного отримання інформації та ст. 159 КК Грузї̈ «Порушення таємниці особистої переписки, телефонних переговорів або повідомлень, переданих іншим способом» - щодо незаконних операцій з особистою кореспонденцією осіб без згоди останніх [4].

На перший погляд ст.ст. 158-159 мають схожість, регулюючи одну i ту саму сферу, але насправді остання акцентує на протиправному ознайомленні з інформацією, тобто на фактичному доступі до вже фізично відтворених відомостей, перебуваючи на тому чи іншому носії інформації. Натомість ст. 158 КК Грузї спеціалізується на перехопленні приватних переговорів у момент їх здійснення або доступу до таких даних через комп'ютер чи мережу. Тобто за порушення таємниці приватної бесіди відповідальність настає за ст. 158, а за ознайомлення з роздруківкою цієї розмови чи аудіозапису після іï закінчення - вже за ст. 159. Таку конструкцію можна вважати скоріше законодавчою особливістю, ніж об'єктивною необхідністю. Додатково варто зазначити звільнення від відповідальності за будь-яке зі згаданих діянь, якщо внаслідок їх вчинення стало відомо про інший злочин чи готування до такого, а отримані відомості були передані до компетентних органів. Дещо схожі зміни були нещодавно внесені й до ст. 182 «Порушення недоторканності приватного життя» КК України, але з огляду на їх невдале формулювання навряд чи можна говорити про реалізацію закладених положень на практиці. КК Грузії у розрізі згаданих статей часто має посилання на спеціальні технічні засоби як знаряддя вчинення злочинів проти приватності. При цьому, на відміну від вітчизняного законодавця, не визнає їх придбання та обіг кримінально-карним діянням. Щоправда, грузинський закон значно ширше трактує поняття «технічний засіб», прирівнюючи до нього будь-який пристрій, спроможний фіксувати, зберігати, перехоплювати чи ретранслювати інформацію (факс, смартфон тощо). Окремі види інформації приватного характеру охороняються й низкою інших статей КК Грузї, часто супроводжуючись словом «таємниця».

Певні розбіжності виникають й щодо розуміння поняття приватного життя. Український кодекс інтерпретує його як сукупність інформації приватного характеру про особу. Натомість грузинський закон додатково виділяє персональні дані. Окреслений підхід можна пояснити притаманною КК Грузї деталізацією норм, що спрощує кримінально-правову кваліфікацію. Крім того, основні норми, відповідальні за охорону приватної життєдіяльності, в КК Грузії розміщуються послідовно одна за одною, чого не дотримується вітчизняний кодекс. У КК України профільні статті розкидані по розділу $\mathrm{V}$ «Кримінальні правопорушення проти виборчих, трудових та інших особистих прав і свобод людини і громадянина». Наприклад, недоторканність приватного життя забезпечує - ст. 182, а таємницю комунікації - ст. 163, що видається дивним з огляду на охорону різних аспектів у межах одного правового інституту [5]. Щоправда, така архітектура притаманна не тільки КК України. Норма, що регулює охорону інформації, що становить особисту або сімейну таємницю, у ст. 179 КК Республіки Білорусь перебуває в межах глави 21 «Злочини проти устрою сімейного відносин та інтересів неповнолітніх», поряд зі ст. 178, що курирує питання розголошення лікарської таємниці [6]. Якщо подивитися на співіснування особистої таємниці поряд із сімейною, то з логікою такого розміщення умовно можна погодитися, проте наявність тут лікарської таємниці виглядає недоцільною. Особливо з огляду на існування глави 23 «Злочини проти конституційних прав і свобод людини і громадянина», де перебуває ст. 203, що регулює таємницю комунікації. Загалом за змістом закладених положень кодекс більше схожий на грузинський, а за принципами розміщенням норм - на український, але в більш хаотичному його вигляді. 
Ще одним особливим підходом можна вважати ст. 147 КК Республіки Казахстан. Частина перша згаданої статті встановлює відповідальність за недотримання заходів щодо захисту персональних даних особою, на яку покладено обов'язок прийняття таких заходів, а частина друга забезпечує охорону особистої та сімейної таємниці [7]. У такому розумінні чітке розмежування окреслених категорій виглядає більш доцільним та вдалим.

Повертаючись до законодавства України та Грузії, варто наголосити на певних особливостях питань регламентації відповідальності. Санкції КК Грузії характеризуються більшими строками обмеження волі порівняно з вітчизняним. Крім того, грузинський кодекс регламентує відповідальність юридичних осіб (штраф та примусова ліквідація), на відміну від КК України, який не визнає таких осіб суб'єктами злочину. Щоправда, певні кроки в цьому напрямі були зроблені Верховною Радою України: у 2009 р. було прийнято Закон України «Про відповідальність юридичних осіб за вчинення корупційних правопорушень», якій вже через рік втратив чинність. Новою спробою було прийняття у 2014 р. Закону України «Про внесення змін до деяких законодавчих актів України щодо виконання Плану дій щодо лібералізації Європейським Союзом візового режиму для України стосовно відповідальності юридичних осіб», але для повноцінного функціонування такого інституту виникла потреба внести зміни до низки законів, чого не було зроблено [8, с. 112-113]. А.П. Гаврилішин зазначає, що цей правовий інститут у вітчизняній доктрині встановлює відповідальність юридичних осіб за двадцятьма сімома статтями Особливої частини КК України, однак через низку проблем відсутні провадження та вироки суду по таких справах [9, с. 160]. Варто зазначити, що інструментарії для впливу на юридичну особу порушника з боку держави маються вдосталь і зараз, однак вони регламентуються низкою інших актів, тому їх дублювання в межах кримінального законодавства має сумнівний характер.

Розглядаючи санкції статей КК Грузії, не можна обійти увагою особливості призначення штрафу. Сума останнього визначається судом відповідно до обставин коректної справи з урахуванням тяжкості злочину та матеріального положення підсудного. При цьому вона не може бути меншою 500 ларі або 2000 ларі, якщо санкція передбачає обмеження волі на строк від трьох років. У процесі конвертації вказані суми співвідносяться з розміром штрафу, передбаченого вітчизняним законодавством. 3 огляду на те, що середній заробіток у Грузії та Україні приблизно однаковий, можна констатувати однаково обтяжливий характер штрафу для засудженої особи. Утім обидва кодекси не встановлюють прямої залежності розміру грошового стягнення від реального рівня доходу підсудного, хоча КК Грузії має більшу гнучкість. 3 цього приводу звернемося до досвіду Естонії, яка нині є однією з найбільш безпечних країн Європи. Призначення покарань відбувається згідно з положеннями Пенітенціарного кодексу Естонської Республіки (далі - ПК Естонської Республіки) від 06.06.2001 р. Регламентація «Грошового стягнення» визначається ст. 44 кодексу передбачає його в розмірі від 30 до 500 денних ставок. Остання обраховується із середньоденного доходу винного із точністю до десяти євроцентів. Сама сума може коригуватися судом залежно від майнового стану особи, але не нижче за 10 євро. Для юридичних осіб обрахунок грошового стягнення проходить за іншою формулою: або в твердій сумі від 4 тис. до 16 млн євро чи у відсотковому відношенні до оборотних коштів за господарський рік [10]. Цінність розглянутого підходу полягає в тому, що більш вдало забезпечує виконання превентивної та виховної функції покарання. Майновий стан кожної особи різний, тому призначення однакового розміру для кожного буде мати різні наслідки. Залежність розміру штрафу від суми доходу, з одного боку, забезпечує рівно-обтяжливі наслідки, що співмірні ступеню вини кожного підсудного, а не тільки для особи з невеликим доходом; а з іншого -забезпечує справедливість у процесі призначення покарань. Дещо подібне пропонується в робочому варіанті проєкту КК України, нещодавно опублікованому для громадського обговорення робочою групою при Президентові України. У ньому пропонується визначати розмір штрафу у відповідній кількості так званих «розрахункових ставок», сума якої дорівнює 100 грн. І хоча відв' язка штрафу від розміру неоподаткованого мінімуму доходів громадян $є$ позитивним моментом, по суті, являє собою взяту зі стелі суму без соціально-економічного обґрунтування і нічого не змінює [11].

Аналізуючи суворість покарань визначених законодавствами Грузії та Україні, варто звернутися до положень Кримінального кодексу Молдови. Норми відповідальні за охорону інформації приватного характеру, з ознаками таємниці якого характеризується порівняно ліберальними санкціями. До прикладу: санкції ст. 177 «Порушення недоторканності приватного життя» та 178 «Пору- 
шення таємниці листування» передбачають покарання у вигляді штрафу або визначеної кількості годин неоплачуваної праці на користь суспільства [12]. До речі, для розрахунку штрафу використовується аналогічні нормам ПК Естонської Республіки так звані «умовні одиниці». Позбавлення волі ж застосовується лише в кількох випадках, наприклад: вчинення аналогічних злочинних діянь із використанням службового положення або з використанням спеціальних технічних засобів. Тобто можна зробити висновок, що норми кримінальних кодексів України та Грузії $є$ суворішими порівняно з іншими країнами.

Окремо розглянемо реформування правоохоронної системи Грузії, розпочате після середини 2000-х рр. та проголошення політики нульової толерантності до злочинності, що справило значний вплив на чинний Кримінальний кодекс. Комплексна державна політика була успішною, призвівши до значного зменшення рівня злочинності. За оцінками Світового банку, тільки в перші 4 роки загальна кількість крадіжок в Грузї зменшилася на 50\%, а кількість озброєних пограбувань - на 80\%. Паралельно зростала й довіра до поліції: з 10\% у 2003 р. до майже 84\% у 2010 р. [13, с. 21, 23]. Однак швидкі результати досягалися не без помилок, зловживань та порушення прав і свобод людини. Згідно з даними Фонду грузинського відкритого суспільства, станом на 2009 р. розмір виправдувальних вироків у державі становив 0,1\%, а питома вага угод про визнання провини збільшилася до 57\%. Водночас відбулося значне збільшення кількості засуджених: у 2010 р. на 100000 населення доводилося 538 ув'язнених осіб - це п'яте місце у світі і один із найвищих показників у східноєвропейському регіоні, а загалом за період 2003-2010 рр. цей показник зріс на 300\% [14, с. 13-14]. Цифри свідчать про проведення на той час у державі доволі агресивної політики з протидії злочинності з певними перегинами, що призводили до порушеннями прав і свобод людини. У цього сенсі доречно поглянути на дані щодо розвитку демократії так званого «індексу демократії, що з 2006 р. складається британською компанією Economist Intelligence Unit. Згідно зі звітом, за підсумками 2006 р. Грузія посіла 104 місце з 112 демократичних країн (97 - за рівнем громадянських свобод), режим якої визнавався як «гібридний», межуючи з блоком авторитарних країн, що посідали 113-167 сходинки. Закладений тренд зберігався потягом років, наприклад у 2010 р. він покращився на одну позицію [15; 16]. Ще одним аргументом слугує збіль- шення звернень громадян Грузії до Європейського Суду з прав людини за 2008-2009 рр. за захистом порушених прав (більше ніж 10 разів). У співвідношенні до населення країни це другий показник після Словенії в Європі на той час [17].

Для повноти картини не можна обійти увагою й кількісні показники скоєних злочинів. На жаль, Міністерство внутрішніх справ Грузї не надає детальних даних щодо кількості вчинених злочинів у розрізі окремих статей КК Грузї, але загалом злочинів проти прав і свобод людини у 2018 р. зафіксовано 2748; проти 3172 у 2019 р. [18]. За даними Генеральної прокуратури України щодо кількості зареєстрованих кримінальних правопорушень проти виборчих, трудових та інших особистих прав і свобод людини і громадянина у 2018 р. - 7059, при 7219 - у 2019 р. [19]. Враховуючи, що Грузія $\epsilon$ більше ніж у десять разів меншою за населенням країною, можна констатувати скоєння значно більшої кількості злочинів у цій сфері порівняно з Україною. Проте необхідно враховувати й рівень латентності злочинів, на який, за оцінками окремих міжнародних вчених, припадає не менше 50-60\% від загальної кількості вчинених злочинів [20, с. 26; 21, с. 90]. В Україні ж з огляду на невисокий рівень довіри до правоохоронних та судових органів рівень необлікованих злочинів ще вищий за згадані цифри. Точної цифри немає, проте, наприклад, О.М. Ігнатов, посилаючись на підрахунки вітчизняних вчених, у своїх дослідженнях показує, що співвідношення кількості зареєстрованих і латентних злочинів може варіюватися від 1:3 до 1:10 [22, с. 214].

Не останню роль у цьому відіграють небажання громадськості захищати свою приватну сферу життєдіяльності та низький рівень обізнаності у своїх правах, а іноді й просто відсутність відповідного правового регулювання. Вирішенням наявного пласту проблем вбачається не тільки вироблення правових інструментів, але й проведення дієвої державної політики, спрямованої на убезпечення інформації приватного характеру з ознаками таємниці в умовах науково-технічного прогресу.

Висновки. Підбиваючи підсумки вищевикладеного, варто зазначити, що кримінально-правова охорона різних аспектів інформації приватного характеру з ознаками таємниці за законодавством України та Грузії має свої особливості. Положення КК Грузії виглядають більш сучасними в контексті регламентації питань відповідальності та деталізації законодавчого наповнення. Натомість КК України виглядає більш конкретним, норми чітко структуровані та лаконічно сформульовані, змен- 

та науково-методичне забезпечення

шуючи потенційні ризики зловживань та помилок під час кваліфікації. Утім обидва кодекси не позбавлені недоліків, наприклад: застарілі підходи до призначення штрафу, розмитість положень та існування конкуренції окремих норм.

Окреслюючи напрями модернізації та осучаснення вітчизняного кримінального законодавства, варто зосередитися на кількох напрямах:

1) проаналізувати доцільність внесення юридичної особи як суб'єкта злочину, тим самим остаточно поставити крапку в цьому питанні;

2) провести осучаснення кримінально-правових норм, відповідальних за убезпечення різних сфер приватної життєдіяльності людини та вироблення ґрунтовної державної політики в цьому напрямі;

3) проаналізувати перспективність обрахунку розміру штрафу не у вигляді певної кількості неоподаткованих мінімумів доходів громадян, а у прив'язці до розміру заробітку підсудного, що $\epsilon$ більш сучасним підходом.

Не варто приймати за чисту монету й успіхи зарубіжних реформ у сфері правоохоронної системи, адже швидкі зміни не завжди відбувається повністю з дотриманням прав і свобод людини. Це ситуація, де результат не обов'язково виправдовує засоби. Особливо це стосується країн, де людина, їі життя і здоров'я, честь і гідність, недоторканність і безпека визнаються найвищою соціальною цінністю.

\section{Література}

1. Баулін Ю.В. Сучасне кримінальне право України: підсумки, тенденції, перспективи розвитку. Питання боротьби зі злочинністю: збірник наук. пр. Харків : Право, 2012. Вип. 23. С. 29-42.

2. Лунєєв В.В. Преступность XX века: мировые, региональные и российские тенденции. 2-е, перераб. и доп. Москва : Волтерс Клувер, 2005. 868 с.

3. Сташис В.В. Основні новели нового Кримінального кодексу України. Вісник Академії правових наук України. 2003. № 2-3 (33-34). С. 612-626.

4. Уголовный кодекс Грузии от 22 июля 1999 года № 2287-вс. По состоянию на 29.05.2019 года. URL: https: / / matsne.gov.ge/ka/document/download/ 16426/143/ru/pdf

5 Кримінальний кодекс України від 5 квітня 2001 року № 2341-ІІІ. Відомості Верховної Ради України. 2001. № 25-26. Ст. 131. URL: https://zakon. rada.gov.ua/laws/show/2341-14

6. Уголовный кодекс Республики Белорусь от 9 июля 1999 г. № 275-3. URL: http://www.pravo.by/ document/?guid=3871\&p0=hk9900275
7. Уголовный кодекс Республики Казахстан от 3 июля 2014 года № 226-V (с изменениями и дополнениями по состоянию на 11.01.2020 г.). URL: https:// online.zakon.kz/document/?doc_id=31575252\&doc_id2= 31575252\#activate_doc=2\&pos=158;-94\&pos2=2294;-92.

8. Цимбалюк В. Зарубіжний досвід кримінальної відповідальності юридичних осіб та перспективи України. Історико-правовий часопис. 2014, № 1. С. 112-116. URL: http://nbuv.gov.ua/UJRN/ ipch_2014_1_26

9. Гаврилішин А.П. Проблеми кримінальної відповідальності юридичних осіб. Юридичний вісник. Повітряне і космічне право. 2018. № 2. С. 160-165. URL: http://nbuv.gov.ua/UJRN/Npnau_2018_2_25.

10. Пенитенциарний кодекс Естонии от 06.06.2001 г. RT । 2001, 61, 364. URL: https://v1.juristaitab.ee/ sites/www.juristaitab.ee/files/elfinder/ru-seadused/ ПЕНИТЕНЦИАРНЫЙ\%20КОДЕКС\%2015.03.2019.pdf

11. Проєкт Кримінального кодексу України. Контрольний пакет станом на 15 вересня 2020 року. URL: https://newcriminalcode.org.ua/ upload/media / 2020/09/16/1-kontrolnyj-proektkk-15-09-2020.pdf

12. Уголовный кодекс Республики Молдова от 18.04.2002 г. № 985-XV. URL: http://lex.justice.md/ $\mathrm{ru} / 331268 /$

13. Боротьба з корупцією у сфері державних послуг: Хроніка реформ у Грузії. Видання Світового банку. URL: http://documents1.worldbank.org/ curated/ru/317321468244165162/pdf/664490PUBOUK RA0eorgiaOBook0Ukranian.pdf

14. Crime and excessive punishment: the prevalence and causes of human rights abuse in georgia's prisons. Open society Georgia foundation. Tbilisi, 2014. P - 79.

15. Democracy index 2007. The Economist Intelligence Unit Limited. URL: https://www. economist.com/media/pdf/DEMOCRACY_INDEX_2007_ v3.pdf.

16. Democracy index 2010. The Economist Intelligence Unit Limited. URL: https://graphics.eiu. com/PDF/Democracy_Index_2010_web.pdf.

17. European Court of Human Rights - Analysis of Statistics 2010. URL: https://www.echr.coe.int/ Documents/Stats_analysis_2010_ENG.pdf.

18. Statistics of Registered Crime All Investigative Agencies of Georgia. Minister of Internal Affairs of Georgia. From 01-01 Till 12-31. URL: https://info. police.ge/page?id=170\&parent_id=115.

19. Про зареєстровані кримінальні правопорушення та результати їх досудового розслідування за січень-грудень 2018-2019 рр. : статистична інформація Генеральної прокуратури України. URL: http:// www.gp.gov.ua/ua/stat.html. 
20. Кримінологія: Загальна та Особлива частини : підручник / І.М. Даньшин, В.В. Голіна, М.Ю. Валуйська та ін.; за заг. ред. В.В. Голіни. 2-ге вид. перероб. і доп. Харків : Право, 2009. 288 с.

21. Кримінологія : підручник / А.М. Бабенко, О.Ю. Бусол, О.М. Костенко та ін.; за заг. ред. Ю.В. Нікітіна, С.Ф. Денисова, Є.Л. Стрельцова. 2-ге вид., перероб. та допов. Харків : Право, 2018. 416 с.

22. Игнатов А.Н. Общая характеристика факторов латентности убийств. Ученые записки Таврического национального университета им. В.И. Вернадского. Серия: Юридические науки. 2011. Т. 24 (63). № 2. C. 213-219.

Хлопов А. O., аспірант кафедри кримінального права та кримінології факультету № 6 Харківського національного університету внутрішніх справ 